\title{
Analyzing the Use of P2P Lending Mobile Applications in Greater Jakarta
}

\author{
Nancy Adistyasari ${ }^{1}$, Refi Kautsar Firmansyah ${ }^{2}$, Willy Gunadi ${ }^{3}$ \\ ${ }^{1,2,3}$ Business Management, Management Department, Binus Business School Master Program, \\ Bina Nusantara University, Jakarta, Indonesia \\ email: nancy.adistyasari@binus.ac.id ${ }^{1}$, refi.firmansyah@ binus.ac.id $^{2}$, wgunadi@binus.edu ${ }^{3}$
}

\begin{abstract}
$\mathrm{P} 2 \mathrm{P}$ lending emerged as a result of the digital revolution that met people's needs to borrow funds in an easy way, and became an alternative to other conventional lending methods, such as lending money to banks. With the increasing access to Internet usage in society, public access to P2P lending applications will also be more open. It is proven by the significant increase of transactions in P2P lending applications in current years. Previous research has focused more on the phenomenon of $\mathrm{P} 2 \mathrm{P}$ lending growth and its relation to the existing financial ecosystem, namely banking, and research that focuses more on MSMEs as P2P lending application users. Therefore, we see the need for research to find out what factors influence the intention to use P2P lending applications, including knowing the positive impact of perceived ease of use, perceived usefulness, trust, user innovation, and government support for attitude towards using the P2P lending applications, and the positive impact of attitude towards use for behavioral intention to use P2P lending applications. The study was conducted by taking a sample of 150 people who had never applied a P2P lending application and were domiciled in Greater Jakarta. The data analysis method used for hypothesis testing was Partial Least Squares Structural Equation Modeling (PLS-SEM). The results show that trust and user innovativeness factors have a positive effect on attitude towards using P2P lending applications and attitude towards use has a positive effect on behavioral intention to use P2P lending applications. Meanwhile, perceived ease of use, perceived usefulness, and government support do not have a positive impact on attitude towards utilizing P2P lending applications.
\end{abstract}

Keywords: Perceived ease of use, perceived usefulness, trust, user innovativeness, government support, P2P lending.

\section{INTRODUCTION}

The digital revolution has changed the culture, habits, and comfort level of society because it makes things easier and faster. Citing data from [7], of Indonesia's total population of 264.16 million people, as many as $64.8 \%$ or 171.17 million people are Internet savvy, and the growth of Internet users reached $10.12 \%$ in 2018 compared with 2017, or an increase of 27.92 million people and Java Island still being the region with the highest user contribution. The high growth of Internet users opens opportunities for the growth of digital-based activities to become more massive, one of which includes a digital economy known as fintech which is defined as the evolution of the meeting between technological developments and financial services [60].

The development of the fintech industry not only facilitates the public to utilize technology to conduct financial transactions, but also to borrow funds or what is commonly called fintech lending. The growth of fintech lending penetration has come to the attention of the government, particularly the Financial Services Authority as an institution that oversees this industry. It has recorded significant growth, both in terms of loan accumulation and the number of accounts. The growth of fintech lending is also influenced by changes in people's consumption patterns. Consumption behavior is formed under the influence of various factors, and when social and historical conditions change, some of these consumption behaviors may become important priorities, while others become meaningless [42]. This change in consumption patterns and the digital revolution has made it easier for people to get alternative sources of funds to meet their needs and choose fintech lending as a solution for making loans. The development of fintech companies in general shows significant growth and fintech related industries are promising [26]. Furthermore, for Indonesia, there are opportunities for fintech development [22]. Fintech lending in Indonesia is estimated to have a growth rate of 214\% from 2018-2020 [61]. The development of this aggressive fintech lending can have business potential for service providers, and can also be a source of funding for service users (borrowers) so as to form advanced ecosystem which potentially disruptive to the existing financial ecosystems. One of the advanced formed financial ecosystems is peer-to-peer lending (P2P lending) where in addition to technological developments, P2P lending applications have also grown significantly due to the high population of people who do not yet have access to the banking system [46].

The development of P2P lending in Indonesia is supported by the Indonesian government, one of which is through regulations that have been issued to regulate P2P lending-related activities. Considering government involvement, this research is related to the role of the government. In this case, the FSA in the fintech industry has been carried out [10], so the factor of government support for the adoption of $\mathrm{P} 2 \mathrm{P}$ lending is also interesting to investigate. 
Nancy Adistyasari et al., International Journal of Advanced Trends in Computer Science and Engineering, 9(2), March - April 2020, 2010 - 2020

Despite the rapid growth of $\mathrm{P} 2 \mathrm{P}$ lending, for Indonesia itself it turns out that public awareness of P2P lending services can still be considered lacking. Based on a survey report from [19], out of 1,500 respondents, around $47.5 \%$ of the respondents were not aware at all about fintech services. Then for the fintech service itself, most respondents $(82.7 \%)$ knew that the fintech service is related to digital wallet. Meanwhile, respondents' awareness of P2P lending services was below $25 \%$.

Then, based on [18], from the number of people who were aware of P2P lending, there were several reasons they did not or did not want to use it where the most of $35.02 \%$ of the respondents felt uninterested. Referring to this data, it can be seen that there are problems related to the adoption of P2P lending services, so that the factors that can increase people's intention to adopt $\mathrm{P} 2 \mathrm{P}$ lending application services are interesting to be searched.

Furthermore, there are problems that arise related to the use of $\mathrm{P} 2 \mathrm{P}$ lending in Indonesia, causing public distrust to use P2P lending. As of June 2019, based on data from the Jakarta Legal Aid Institute (LBH) there were 4,500 complaints related to fintech lending. This makes the level of consumer confidence decrease [63]. From an investigation by the Investment Alert Task Force (SWI) as of August 2019, around 1,230 fintech lending companies have been found to have the potential to harm the community [2]. Besides the problem of illegal fintech lending, another problem that arises is the problem of billing that is not in accordance with the rules and ethics that are troubling borrowers [1].

Several previous studies have analyzed related factors of adoption of fintech, but the focus is more on fintech for payments such as electronic payments or electronic wallets [15], [32], [59]. Regarding fintech in Indonesia, several studies have analyzed user behavior towards the adoption of fintech, but the research focuses on the use of fintech for online transportation and digital payment platforms [28], [37]. Meanwhile, related to P2P lending in Indonesia, previous research has been more concerned with the phenomenon of P2P lending growth and its relation to the existing financial ecosystem, namely banking [41], [64]. In terms of user intentions to adopt P2P lending, several studies that have been conducted focus more on MSMEs as P2P lending application users [49], [65], [67], [71]. For research in Indonesia itself there has also been specific research related to the adoption of P2P lending for individual users [23], [77], [79], [85], but the number is still relatively limited, so it needs to be examined whether user characteristics also influence the level of P2P lending adoption.

Previous research has been conducted related to the intention of using fintech with the TAM (technology acceptance model) method [35], [39]. In these studies, they conducted research related to individual perceptions of the use of P2P lending application services, and based on this, the method used to explain the perceptions of individuals is the TAM model. The TAM model was chosen in this study because it is a multivariable model that can be used to predict the intention to use technology based on individual perceptions [5]. In this study, there are additional variables of the TAM model in the form of perceived ease of use and perceived usefulness. Other variables such as trust, user innovation, and government support will also be used.

Based on the existing literature, there is no research that discusses the interrelation of the variables that have been determined in this study, related to the adoption of P2P lending. Thus, based on the above phenomenon, the purpose of this study is to analyze the relationship between the variables of perceived ease of use, perceived usefulness, trust, user innovativeness, and government support on the intention to adopt P2P lending application services.

\section{THEORITICAL REVIEW}

\subsection{Fintech Lending}

Technological developments continue to expand and have an impact on various sectors, including the economic sector, and open up opportunities for technological innovation in the financial sector, one of which is financial technology (fintech). Fintech is a new solution where there is the development of innovative applications, processes, products, or incremental or disruptive business models in the financial services industry [3]. Fintech is the application of technology in finance that aims to make financial services more efficient [52]. Fintech generally aims to attract customers with products and services that are more user friendly, efficient, transparent, and automatic [24]. Fintech lending utilizes digital technology to register account, verify borrower documents, and determine loan eligibility so as to reduce operational costs. Fintech lending also develops a platform that is simple and easy to use so that it can attract a lot of consumer interest. Then, in the fintech lending model, the assessment of consumers is adjusted using behavioral data to identify typical attributes to determine interest rates. This is also supported by the provision of funds from both lending and retail institutions [61].

\subsection{Technology Acceptance Model (TAM)}

TAM is a theory used to explain how users accept and use a particular technology. The TAM model was introduced by Davis in 1989 to explain the behavior of acceptance of computer technology. In the TAM model, there are two main constructs that are considered to influence behavioral intention decisions about a technology. The two main constructs are perceived usefulness and perceived ease of use. In the initial model, the two main constructs are used to explain the effects of attitudes on the use of a technology which will then be used to explain the actual use of the system. Then, the two main constructs can also be influenced by external variables [20]. The final version of TAM suggests that perceived usefulness and perceived ease of use have a direct influence on individual behavioral intentions [83]. 
Nancy Adistyasari et al., International Journal of Advanced Trends in Computer Science and Engineering, 9(2), March - April 2020, 2010 - 2020

The TAM model can constantly clarify variations in consumer intentions and behaviors towards the acceptance of a technology, so that it has been considered valid to use in analyzing the adoption of information technology. One of the strengths of the TAM model lies in its simple model [84]. This TAM model has been widely used to analyze the adoption of information technology such as computers, Internet banking, mobile Internet, e-payment, and e-wallet.

\subsection{Perceived Ease of Use}

Perceived ease of use is a parameter that shows the level of consumer confidence that the technology can be used easily without significant effort [21]. Some indicators that show a technology is easy to use are the technology is easy to learn, easy to control, easy to understand and clear, flexible, easy to master, and easy to use [21], [80]. In the fintech context, perceived ease of use refers to the extent to which consumers feel comfortable using and making efforts in the process of trying to understand the fintech services [35]. Then, it was said in another study that other indicators related to the perceived ease of use of fintech services were the ease of the operation process and the ease of downloading the service [13].

Related to the fintech service acceptance study, the previous study showed that perceived ease of use has a positive effect on attitudes towards fintech use [17], [53]. Then, in another study related to the evaluation of the perspective of users of P2P lending mobile applications, it shows that perceived ease of use has a positive effect on attitudes towards using P2P lending mobile applications [48].

\subsection{Perceived Usefulness}

Another major construct in the TAM model is perceived usefulness. Based on the diffusion theory, users are willing to adopt an innovation if they consider it to have certain advantages over alternative solutions that are already available [66]. In the context of fintech, users will choose to adopt fintech services if they think that fintech applications have a positive impact on them [68]. Furthermore, on studies related to the adoption of mobile payments, the perception of the usefulness is defined as the level of someone's trust that by conducting transactions in a mobile manner can help their daily activities so that it is more effective and efficient [54]. Then, it was mentioned that the main use of fintech technology lies in the depth of user data information and the mapping of user knowledge [13].

Perception of usefulness also shows a positive influence on attitudes towards the use of fintech in several previous studies [17], [35]. In another study related to the evaluation of the perspective of users of $\mathrm{P} 2 \mathrm{P}$ lending mobile applications, it shows that perceived usefulness has a positive effect on attitudes towards the use of $\mathrm{P} 2 \mathrm{P}$ lending mobile applications [48].

\subsection{Trust}

Trust can be interpreted that the trustee believes that the party given the trust has good intentions [17]. Trust in service providers is defined as customer confidence that the service provider has integrity and is reliable [76]. Trust can be seen in two aspects, namely customer trust in service providers and trust in the technology used [12]. In the context of the adoption of a technology, the concept of trust is related to the intention or belief in using the technology [14].

In another study of fintech, the trust variable is an important factor because it is related to the personal data needed for the service [35]. Regarding the adoption of fintech lending with a peer-to-peer form in Malaysia, a study revealed that the trust factor has a significant positive effect on the adoption of the technology from the investor side [81].

\subsection{User Innovativeness}

Highly innovative groups of individuals tend to accept uncertainty about something and have more prejudice to innovate [35]. The nature of this innovation illustrates the level of willingness of an individual to try something new, whether a new product or service [35], [86]. Another research stated that the nature of innovation in a person is an innate trait related to the psychological need for uniqueness, and social identification plays an important role in that trait. The innovative nature of the user is an innate trait that can represent one's personality [8].

In some studies, related to mobile wallet, it is stated that innovativeness has a significant positive effect on the intention to use the technology [70]. Related to fintech adoption studies, previous studies have shown that innovativeness has a positive effect on attitudes towards the use of fintech services [35].

\subsection{Government Support}

The government can provide support to increase the level of penetration of the use of a technology so as to give credibility and feasibility to a technology [50]. The greater the level of government support felt by consumers, the greater the potential for the person to adopt a technology [55].

Related to fintech, previous studies said that government support is one of the driving factors in fintech adoption [16]. In some studies, related to Internet banking adoption, it was mentioned that government support was the main supporting factor for Internet banking adoption because the government support gave users confidence that the technology would operate in an orderly and good manner [50].

\subsection{Attitude towards Using Technology}

Attitude (attitude) is something that is felt by the user, both positive and negative feelings, when they have to do something that has been set [21]. In another definition, attitude is a subjective assessment and individual tendency related to something [87]. In studies related to TAM, attitude variables have a relationship with someone's intention to use a technology [34], [47]. 
Nancy Adistyasari et al., International Journal of Advanced Trends in Computer Science and Engineering, 9(2), March - April 2020, 2010 - 2020

In the study of technology adoption related to the banking world, there is a positive relationship between user attitudes toward certain technologies with the intention of adopting the technology [33], [74]. Then, related to the study of adoption of fintech services, attitudes toward use also have a positive effect on the intention to use fintech services [35].

\subsection{Behavioral Intention to Use}

In the other TAM model construct to analyze the level of adoption of a technology, the user intention construct is commonly used as the dependent variable in the TAM model. A person's intention towards a behavior can represent the actual person's behavior [25]. Behavior intention to use is defined as the level of one's intention to perform a particular behavior or action [21]. Behavioral intention in the previous study was mentioned as an important factor in the successful adoption of a technology because psychologically a person would not use a technology if one did not have the intention to use it before [51]. In the context of technology adoption, the intention to use can be interpreted as the level of someone having the intention to use the new technology [17].

\subsection{Hypotheses and Research Models}

In this study, the theory used as the basis for making the research model is TAM which has two main constructs of perceived ease of use and perceived usefulness. Previous studies show that perceived ease of use and perceived usefulness have a significant positive effect on attitudes towards the use of a technology [84]. In several other studies related to the acceptance of mobile wallet technology, perceived ease of use and perceived usefulness positively influence individual attitudes towards the use of mobile wallet [4]. Associated with studies of acceptance of fintech services, previous studies have shown that perceived ease of use has a positive effect on attitudes towards the use of fintech [17], [53]. It shows that the comfort provided by service providers in using these services affects the user's attitude towards the use of the technology. Perception of usability also shows the effect of a positive attitude toward the use of fintech in several previous studies [17], [35]. Then in another study related to the evaluation of the perspectives of users of $\mathrm{P} 2 \mathrm{P}$ lending mobile applications, it conveyed that perceived ease of use and perceived usefulness positively influenced attitudes towards using P2P lending mobile applications [48]. Based on the results of these studies, the hypotheses in this study are:

Hypothesis 1: Perceived ease of use has a positive effect on attitude towards using P2P lending applications.

Hypothesis 2: Perceived usefulness has a positive effect on attitude towards using P2P lending applications.

An analysis of the influence of trust on the adoption of a technology was done by several previous studies [14], [32]. Trust is important in the adoption of technology. Consumers will easily switch to another technology if their trust in the other technology is higher than the technology that is being used [32]. A low level of consumer confidence in a technology can make a low rate of adoption of the technology [75]. Related to the fintech service adoption study, the trust variable also shows a significant positive effect on attitudes towards the use of the fintech service [31], [35]. Based on the results of these studies, the next hypothesis in this study is:

Hypothesis 3: Trust has a positive effect on attitude towards using P2P lending applications.

The nature of innovativeness or the willingness of users or prospective users to try new technologies can affect the rate of adoption of the technology. In previous studies related to the adoption of mobile payments, user innovativeness was discovered to affect the intention to use the technology due to limited knowledge related to the product or service of the technology [43]. Regarding fintech adoption, previous studies have shown that innovativeness has a positive effect on attitudes towards the use of fintech services [35]. Based on the results of these studies, the subsequent hypothesis in this study is:

Hypothesis 4: User innovativeness has a positive effect on attitude towards using P2P lending applications.

One of the external factors that influence the adoption of fintech is support from the government [16], [35]. The government represents good credibility so that with government support in the use of food technology, it can increase the credibility of products and related services [35]. In studies related to e-commerce adoption, government support factors are important to the adoption rate because the government can make policies and rules that can help the adoption of the technology. These policies and regulations may include legal provisions that protect the parties involved in a business transaction, regulations related to the use of the technology, or incentives for those who take part in using the technology [62]. Government support has a positive effect on technology adoption and intention to reuse due to relevant government policies [44]. In previous studies regarding online banking adoption, government support factors had a positive effect on the adoption of these technologies [11], [58]. Based on the results of these studies, the following hypothesis in this study is:

Hypothesis 5: Government supports positively impacts attitude towards using P2P lending applications.

In studies related to TAM, a person's attitude will affect the intention to use a particular technology [27], [69], [88]. In a study of technology adoption related to the banking world, there is a positive relationship between user attitudes toward certain technologies with the intention of adopting the technology [33], [74]. Then, related to the study of the adoption of fintech services, attitudes toward use also have a positive effect on the intention to use fintech services [35]. The same thing is also shown in studies related to the adoption 
of P2P lending mobile applications, where attitudes towards the use of these applications affect the intention to use [48]. Based on the results of these studies, the resulting hypothesis in this study is:

Hypothesis 6: Attitude towards using technology positively impacts behavioral intention to use P2P lending applications.

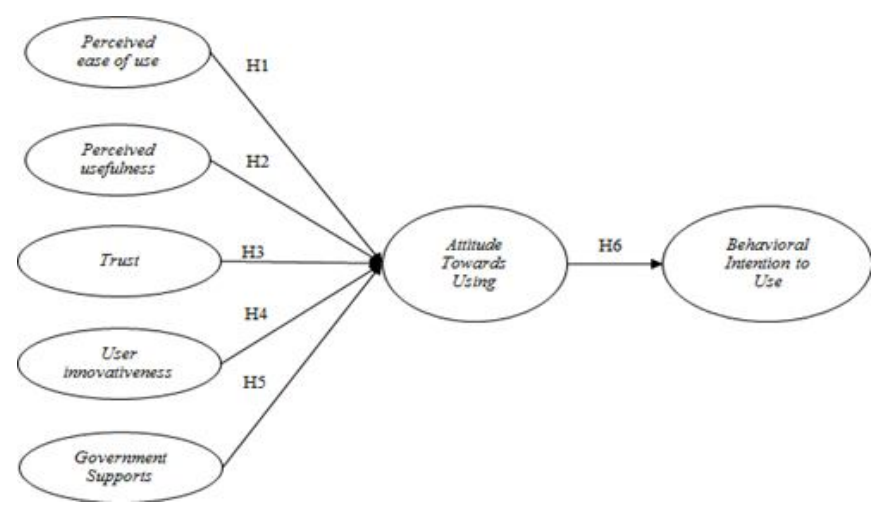

Figure 1: Research Model

\section{RESEARCH METHODOLOGY}

\subsection{Measurement}

The questionnaire used in this study was divided into several sections. The first part aimed to confirm whether the respondents had used fintech lending before and whether they were domiciled in Greater Jakarta. In this section, screening/filtering of respondents was conducted. If they had used fintech lending and/or were domiciled outside Greater Jakarta, then they were immediately directed to exit or complete the questionnaire. Then the respondents got questions related to their knowledge about fintech lending service providers. In the questionnaire, so that respondents who did not understand fintech lending could better understand the concept, a link was given to the site that provided an overview of the scheme, an explanation and illustrations or demonstrations regarding the use of fintech lending. Then in the second part, the questionnaire contained questions about the respondent's identity such as age, gender, domicile, educational background, occupation, income, purpose of making money loans, understanding of the P2P lending scheme, and also the P2P lending applications that the respondent knew about. In the next section, the questionnaire contained questions related to each variable examined using a Likert scale. The questionnaire in this section had 27 questions, 5 questions related to the variable of perceived ease of use [17], [21], [89], 4 questions related to the variable of perceived usefulness [17], [21], [89], 4 questions related to the variable of trust [17], [35], [73], 4 questions related to the variable of user innovativeness [35], [89], [90], 3 questions related to the variable of government support [50], 3 questions related to the variable of attitude towards using technology [17], [21], [35] and 4 questions related to the variable of intention to use [17], [21], [84].

\subsection{Data Collection and Analysis}

This study was a quantitative study using primary data. The population used was the Greater Jakarta community. While the sample in this study was people who lived in the Greater Jakarta area who had never used fintech lending services. The Greater Jakarta area was chosen because it was based on OJK data as of July 2019. From the origin of the account, the majority of lenders and borrowers were from DKI Jakarta province [57].

The technique used in this study is a non-probability sampling type with convenience sampling. The data collection method used in this study was a survey that was distributed online to the respondents. The questionnaire was distributed to 454 people, and 223 respondents responded to the questionnaire. After the data was collected, it was analyzed using the Structural Equation Modeling (SEM) method.

\section{FINDINGS AND DISCUSSION}

\subsection{Data Analysis Results}

The demographics of the respondents are shown in Table 1, as the majority of the respondents are male (54\%). Then, the majority of the respondents have an age range of 26-30 years old $(23 \%)$, and the majority of the respondents are state-owned company employees $(41 \%)$. The educational background of the majority of the respondents is a Bachelor's Degree (63\%). Many of the respondents have a monthly income in the range of Rp. 5,000,001 - Rp. 15,000,000 (41\%). Most of the respondents live in DKI Jakarta (59\%). The majority of the respondents generally make loans for the purpose of shopping for goods outside their daily needs (55\%). Regarding the previous understanding of P2P lending schemes, the majority of them already understood the schemes of $\mathrm{P} 2 \mathrm{P}$ lending (68\%), and the P2P lending service provider that is best known by the respondents is Investree (55\%).

Table 1: Respondent Demographics

\begin{tabular}{|l|l|l|l|}
\hline $\begin{array}{l}\text { Demographic } \\
\text { Profile }\end{array}$ & Category & Total & Percentage \\
\hline \multirow{5}{*}{ Age } & $<26$ & 30 & $20 \%$ \\
\cline { 2 - 4 } & $26-30$ & 34 & $23 \%$ \\
\cline { 2 - 4 } & $31-35$ & 29 & $19 \%$ \\
\cline { 2 - 4 } & $36-40$ & 28 & $19 \%$ \\
\cline { 2 - 4 } & $>41$ & 29 & $19 \%$ \\
\hline \multirow{5}{*}{ Oender } & Male & 81 & $54 \%$ \\
\cline { 2 - 4 } & Female & 69 & $46 \%$ \\
\hline \multirow{5}{*}{ Occupation } & Students & 8 & $5 \%$ \\
\cline { 2 - 4 } & Private Employee & 59 & $39 \%$ \\
\cline { 2 - 4 } & State-Owned & & \\
& Company & 62 & $41 \%$ \\
\cline { 2 - 4 } & Employee & & \\
\cline { 2 - 4 } & Civil Servant & 3 & $2 \%$ \\
\cline { 2 - 4 } & Entrepreneur & 7 & $5 \%$ \\
\cline { 2 - 4 } & Housewife & 7 & $5 \%$ \\
\cline { 2 - 4 } & Others & 4 & $3 \%$ \\
\hline \multirow{5}{*}{ Domicile } & DKI Jakarta & 89 & $59 \%$ \\
\cline { 2 - 4 } & Bogor & 4 & $3 \%$ \\
\cline { 2 - 4 } & Depok & 14 & $9 \%$ \\
\cline { 2 - 4 } & Tangerang & 24 & $16 \%$ \\
\cline { 2 - 4 } & Bekasi & 19 & $13 \%$ \\
\hline
\end{tabular}


Nancy Adistyasari et al., International Journal of Advanced Trends in Computer Science and Engineering, 9(2), March - April 2020,2010 - 2020

\begin{tabular}{|c|c|c|c|}
\hline $\begin{array}{l}\text { Demographic } \\
\text { Profile }\end{array}$ & Category & Total & Percentage \\
\hline \multirow{4}{*}{ Education } & $\begin{array}{ll}\text { Senior } & \text { High } \\
\text { School } & \end{array}$ & 13 & $9 \%$ \\
\hline & Diploma & 3 & $2 \%$ \\
\hline & $\begin{array}{l}\text { Bachelor's } \\
\text { Degree }\end{array}$ & 94 & $63 \%$ \\
\hline & $\begin{array}{l}\text { Master's/ } \\
\text { Doctorate }\end{array}$ & 40 & $27 \%$ \\
\hline \multirow{5}{*}{$\begin{array}{l}\text { Monthly } \\
\text { Income }\end{array}$} & < Rp. 5,000,000 & 20 & $13 \%$ \\
\hline & $\begin{array}{l}\text { Rp. 5,000,001 - } \\
\text { Rp. 15,000,000 }\end{array}$ & 62 & $41 \%$ \\
\hline & $\begin{array}{l}\text { Rp. } 15,000,001- \\
\text { Rp } 25,000,000\end{array}$ & 30 & $20 \%$ \\
\hline & $\begin{array}{l}\text { Rp. } 25,000,001- \\
\text { Rp. } 50,000,000\end{array}$ & 20 & $13 \%$ \\
\hline & $>$ Rp. $50,000,000$ & 18 & $12 \%$ \\
\hline \multirow{5}{*}{$\begin{array}{l}\text { Borrow } \\
\text { Money } \\
\text { Intention }\end{array}$} & Daily Needs & 9 & $6 \%$ \\
\hline & Business & 24 & $16 \%$ \\
\hline & Installment & 22 & $15 \%$ \\
\hline & $\begin{array}{l}\text { Expenses Outside } \\
\text { Daily Necessities }\end{array}$ & 83 & $55 \%$ \\
\hline & Others & 12 & $8 \%$ \\
\hline \multirow{2}{*}{$\begin{array}{l}\text { Understanding } \\
\text { the P2P } \\
\text { Lending } \\
\text { Scheme }\end{array}$} & Yes & 102 & $68 \%$ \\
\hline & No & 48 & $32 \%$ \\
\hline \multirow{6}{*}{$\begin{array}{l}\text { Known } \\
\text { Indonesian } \\
P 2 P \text { Lending } \\
\text { Provider }\end{array}$} & KoinWorks & 65 & $34 \%$ \\
\hline & Amartha & 105 & $54 \%$ \\
\hline & Investree & 106 & $55 \%$ \\
\hline & Modalku & 77 & $40 \%$ \\
\hline & Akseleran & 58 & $30 \%$ \\
\hline & Others & 15 & $8 \%$ \\
\hline
\end{tabular}

Validity and reliability tests were also carried out on the main research data from all respondents. The loading factor was the parameter reviewed in the validity test. Then the parameters reviewed in the reliability test were the AVE value and composite reliability. Besides these parameters, an assessment was also carried out on the discriminant validity, where the value of AVE for each construct should be greater than the correlation between the construct and other constructs. The limitation of the factor loading value to be able to meet the validity test criteria is above 0.5 [29], [30]. Meanwhile, the limit for AVE is above 0.5 and the limit for the composite reliability value is 0.7 . The results of the validity and reliability tests in the main research can be seen in Table 2 and Table 3.

Table 2: Validity and Reliability Test Results

\begin{tabular}{|l|c|c|c|c|}
\hline \multicolumn{1}{|c|}{ Variable } & Item & $\begin{array}{c}\text { Factor } \\
\text { Loading }\end{array}$ & AVE & $\begin{array}{c}\text { Composite } \\
\text { Reliability }\end{array}$ \\
\hline & EAS1 & 0.905 & & \\
Perceived & EAS2 & 0.938 & & \\
Ease of Use & EAS3 & 0.905 & 0.788 & 0.949 \\
(EAS) & EAS4 & 0.938 & & \\
& EAS5 & 0.737 & & \\
\hline Perceived & USE1 & 0.970 & & \\
Usefulness & USE2 & 0.981 & 0.940 & 0.984 \\
(USE) & USE3 & 0.974 & & \\
& USE4 & 0.952 & & \\
\hline Trust & TRU1 & 0.709 & 0.753 & 0.923 \\
\hline
\end{tabular}

\begin{tabular}{|l|c|c|c|c|}
\hline \multicolumn{1}{|c|}{ Variable } & Item & $\begin{array}{c}\text { Factor } \\
\text { Loading }\end{array}$ & AVE & $\begin{array}{c}\text { Composite } \\
\text { Reliability }\end{array}$ \\
\hline (TRU) & TRU2 & 0.894 & & \\
& TRU3 & 0.925 & & \\
& TRU4 & 0.924 & & \\
\hline User & INO1 & 0.870 & & \\
Innovativeness & INO2 & 0.915 & 0.797 & 0.940 \\
(INO) & INO3 & 0.885 & & \\
\hline Government & INO4 & 0.900 & & \\
Support & GOV1 & 0.963 & & \\
(GOV) & GOV3 & 0.970 & 0.935 & 0.977 \\
\hline Attitude & & 0.967 & & \\
Towards & ATT1 & 0.941 & & \\
Using & ATT2 & 0.965 & 0.899 & 0.964 \\
Technology & ATT3 & 0.938 & & \\
(ATT) & & & & \\
\hline Behavioral & INT1 & 0.959 & & \\
Intention to & INT2 & 0.961 & 0.884 & 0.968 \\
Use & INT3 & 0.931 & & \\
(INT) & INT4 & 0.909 & & \\
\hline
\end{tabular}

Table 3: Discriminant Validity Test Results

\begin{tabular}{|l|l|l|l|l|l|l|l|}
\hline & ATT & INT & EAS & GOV & TRU & USE & INO \\
\hline ATT & $\mathbf{0 . 9 4 8}$ & & & & & & \\
\hline INT & 0.859 & $\mathbf{0 . 9 4 0}$ & & & & & \\
\hline EAS & 0.747 & 0.660 & $\mathbf{0 . 8 8 8}$ & & & & \\
\hline GOV & 0.727 & 0.623 & 0.772 & $\mathbf{0 . 9 6 7}$ & & & \\
\hline TRU & 0.819 & 0.819 & 0.756 & 0.618 & $\mathbf{0 . 8 6 8}$ & & \\
\hline USE & 0.665 & 0.521 & 0.814 & 0.759 & 0.554 & $\mathbf{0 . 9 6 9}$ & \\
\hline INO & 0.775 & 0.726 & 0.720 & 0.736 & 0.660 & 0.673 & $\mathbf{0 . 8 9 3}$ \\
\hline
\end{tabular}

Based on Table 2, the factor loading value for all questionnaire items is greater than 0.5 , so that all questionnaire items pass the validity test. For the AVE parameter, all variables are greater than the value of 0.5 . The composite reliability value for each variable is greater than the value of 0.7 [36]. It indicates that all variables meet the reliability test limits. From Table 3, shows that correlation value for each AVE construct variable to itself is greater than the correlation between the construct variable with others, so that all variables can be determined as valid.

Table 4: Hypothesis Results

\begin{tabular}{|c|c|c|c|c|c|}
\hline $\begin{array}{c}\text { Hypo- } \\
\text { thesis }\end{array}$ & Path & $\begin{array}{c}\text { Path } \\
\text { Coefficien } \\
\boldsymbol{t}\end{array}$ & $\begin{array}{c}\boldsymbol{t} \text { - } \\
\text { Statistic } \\
\boldsymbol{s}\end{array}$ & $\begin{array}{c}\boldsymbol{p} \text { - } \\
\text { Value }\end{array}$ & $\begin{array}{c}\text { Conclusio } \\
\mathbf{n}\end{array}$ \\
\hline H1 & EAS $\rightarrow$ ATT & -0.081 & 0.843 & 0.399 & Rejected \\
\hline H2 & USE $\rightarrow$ ATT & 0.130 & 1.203 & 0.229 & Rejected \\
\hline H3 & TRU $\rightarrow$ ATT & 0.523 & 6.448 & 0.000 & Accepted \\
\hline H4 & INO $\rightarrow$ ATT & 0.284 & 3.511 & 0.000 & Accepted \\
\hline H5 & GOV $\rightarrow$ ATT & 0.159 & 1.528 & 0.127 & Rejected \\
\hline H6 & ATT $\rightarrow$ INT & 0.859 & 32.758 & 0.000 & Accepted \\
\hline
\end{tabular}

The hypothesis test results can be seen in Table 4. This study used a 95\% confidence level, so that the criteria for determining whether a hypothesis is significant or accepted in this study is the $\mathrm{t}$-value $>1.96$ and $\mathrm{p}$-value $<0.05$. If the value of the $\mathrm{t}$-value $<1.96$ and $\mathrm{p}$-value $>0.05$, then the hypothesis is rejected. From this table, it can be viewed that from the 6 hypotheses in this study, 3 hypotheses can be accepted while the 3 other hypotheses are rejected. 


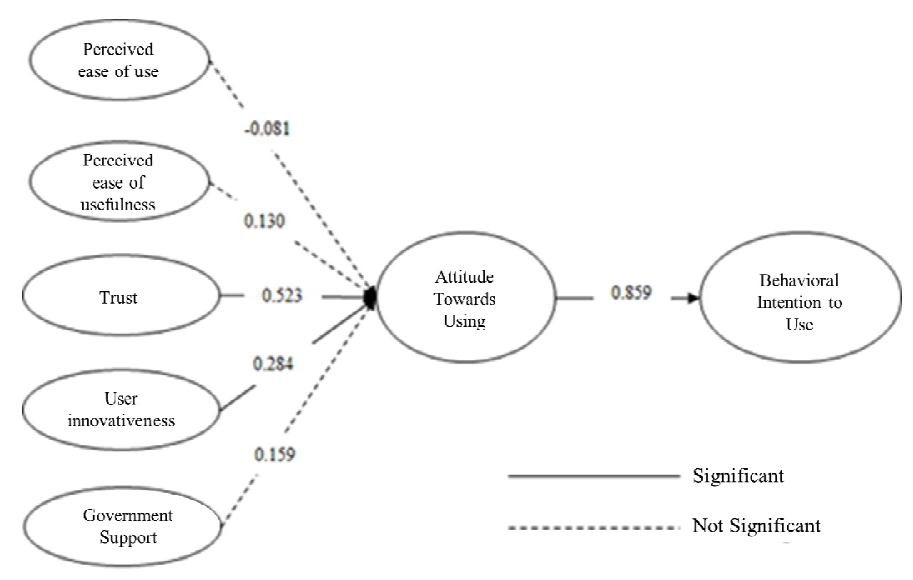

Figure 2: Hypothesis Test Results

\subsection{Discussion}

The ease of use of a technology will not necessarily affect the use of the technology [35], [78]. This is because consumers are not yet familiar enough or have not tried using it [35]. The importance of using P2P lending has not been fully felt by consumers because in general consumers make loans to shop outside their daily needs. As a result, they do not have a strong driving factor for using P2P lending application services. In addition, many consumers are more familiar with conventional lending and borrowing services such as through banks or borrowing through friends or family. With the advancements of information technology, banks have also improved their services related to lending and borrowing facilities, so that consumers feel the option is sufficient for them. The adoption of technology in banking services improves the quality of their services and products [82].

Another factor that influences the attitude of the use of technology is trust [31], [35], [81]. Consumers may refrain from using a new application service because they lack or distrust the service [31] or vice versa that they can switch to another technology if the level of trust in the technology is greater than the technology that is being used [32]. Collaboration with public figure also influential, because trust to digital influencer have a significant and positive effect on a brand attitude [91].

P2P lending application services can be trusted enough, so that they feel a particular service is worth trying or adopting. The positive attitude of consumers towards the use of P2P lending applications that are relatively new is influenced by the nature of consumers who want to try new things affected by social media, since the use of it as a forum for mobile advertising is proven to be able to attract Indonesian people to use the products [92]. Someone who has a high enough user innovativeness tends to have a positive perception of the adoption of a new technology [6].

Support from the government can affect the use of technology [50], [56]. This can be because, for consumers, technology adoption is more likely not to favor external factors such as government support [56]. However, support factors from the government are not significantly relevant to the use of P2P lending application services. This can be caused by the characteristics of the respondents where the majority of the respondents are millennials, who have apathetic characteristics [9]. The millennial generation is considered apathetic towards government policies [38]. This millennial apathy makes them ignore government support, so that it does not affect their attitude towards adopting P2P lending services. In addition, respondents who are skeptical [40], [72] will make them feel distrustful of government support.

In the context of the respondents' positive attitude towards P2P application lending, it will form a positive attitude towards the intention to use the P2P lending application service. The respondents believe that using P2P lending applications is an interesting idea that makes them want to recommend using the service to others. A positive attitude towards a desired behavior will form a positive attitude towards the intention to do so [45].

\section{CONCLUSION}

In adopting the use of $\mathrm{P} 2 \mathrm{P}$ lending applications, the respondents are more concerned with the factor of trust in the use of P2P lending, and the use of P2P lending is also considered stronger as a form of new innovation so as to build user interest in trying it. The most important managerial implication is that $\mathrm{P} 2 \mathrm{P}$ lending applications should be implemented by service providers, namely to focus on variables that are relevant to user trust and innovation, such as raising a positive campaign to increase trust levels, providing friendly customer service, and cooperating with billing services that are more acceptable to users. Then the negative news about P2P lending can be slowly reduced. Meanwhile, to increase the adoption of $\mathrm{P} 2 \mathrm{P}$ lending applications in terms of user innovation, $\mathrm{P} 2 \mathrm{P}$ lending application providers must be more creative in providing new features or using attractive advertisements to make people want to try using P2P lending applications. Service providers can build partnerships with suitable public figures or influencers and also display testimonials from other consumers so that they can increase their trust while running an interesting marketing strategy or creating attention-grabbing promotions and advertisements. On the other hand, this research can also be beneficial for banks to also start collaborating with P2P lending application providers, so that the results of this study can be used to determine strategies for banks in developing P2P lending schemes.

\section{RESEARCH LIMITATIONS}

There are several limitations in this study that can be done in subsequent studies. First, further research can use other variables beyond the six variables used in this study, such as the cost variable, ease of payment variable, benefit variable, or credibility variable from P2P lending provider services. Second, this research can be developed for a wider range of samples; that is, samples that have used P2P lending applications. Furthermore, this research is specifically conducted to determine the adoption of P2P lending 
Nancy Adistyasari et al., International Journal of Advanced Trends in Computer Science and Engineering, 9(2), March - April 2020, 2010 - 2020

applications by prospective borrowers. Meanwhile, currently this $\mathrm{P} 2 \mathrm{P}$ lending application is also much in demand by users as investors or lenders. Therefore, this research can also be developed to determine the adoption of the use of P2P lending applications as lenders. And finally, this research is limited to samples in Greater Jakarta. It would be more useful if this study was also developed more broadly in Indonesia to find out the consistency of the results of the study compared to the sample in Greater Jakarta and could even be done to compare the adoption of P2P lending in Indonesia and other developing countries such as India and China, and advanced countries such as the United Kingdom.

\begin{tabular}{|c|c|c|}
\hline \multicolumn{3}{|l|}{ APPENDIX } \\
\hline Variable & Code & Indicator \\
\hline \multirow{5}{*}{$\begin{array}{l}\text { Perceived Ease } \\
\quad \text { of Use }\end{array}$} & EAS1 & $\begin{array}{l}\text { P2P lending services are easy to } \\
\text { understand. }\end{array}$ \\
\hline & EAS2 & P2P lending services are easy to operate. \\
\hline & EAS3 & $\begin{array}{l}\text { P2P lending services allow flexible } \\
\text { interactions with users. }\end{array}$ \\
\hline & EAS4 & \begin{tabular}{|llll}
$\begin{array}{l}\text { P2P lending services provide useful } \\
\text { guidance. }\end{array}$ & & \\
\end{tabular} \\
\hline & EAS5 & Overall, I find P2P lending easy to use. \\
\hline \multirow{4}{*}{$\begin{array}{l}\text { Perceived } \\
\text { Usefulness }\end{array}$} & USE1 & $\begin{array}{l}\text { P2P lending services make the process of } \\
\text { lending and borrowing faster. }\end{array}$ \\
\hline & USE2 & $\begin{array}{l}\text { P2P lending services make it easier to do } \\
\text { lending and borrowing. }\end{array}$ \\
\hline & USE3 & $\begin{array}{l}\text { P2P lending services can increase the } \\
\text { effectiveness in searching for loans. }\end{array}$ \\
\hline & USE4 & $\begin{array}{l}\text { Overall, I feel that P2P lending can be } \\
\text { useful for lending and borrowing activities. }\end{array}$ \\
\hline \multirow{4}{*}{ Trust } & TRU1 & P2P lending services can be trusted. \\
\hline & TRU2 & $\begin{array}{l}\text { I believe that P2P lending services can } \\
\text { protect my personal data. }\end{array}$ \\
\hline & TRU3 & $\begin{array}{l}\text { P2P lending service providers think about } \\
\text { the interests of their customers. }\end{array}$ \\
\hline & TRU4 & I trust P2P lending services. \\
\hline \multirow{4}{*}{$\begin{array}{c}\text { User } \\
\text { Innovativeness }\end{array}$} & INO1 & $\begin{array}{l}\text { When I found out there was a new product, } \\
\text { I looked for ways to try it. }\end{array}$ \\
\hline & INO2 & $\begin{array}{l}\text { Among my colleagues, I am generally } \\
\text { among the first to try new things. }\end{array}$ \\
\hline & INO3 & I like to experiment with new technology. \\
\hline & INO4 & $\begin{array}{l}\text { In general, I would not hesitate to try new } \\
\text { technology. }\end{array}$ \\
\hline \multirow{3}{*}{$\begin{array}{l}\text { Government } \\
\text { Support }\end{array}$} & GOV1 & $\begin{array}{l}\text { I believe that the government/ state } \\
\text { financial institutions support the use of P2P } \\
\text { lending applications. }\end{array}$ \\
\hline & GOV2 & $\begin{array}{l}\text { I believe the government/ state financial } \\
\text { institutions have introduced/ made laws and } \\
\text { regulations that support the use of P2P } \\
\text { lending applications. }\end{array}$ \\
\hline & GOV3 & $\begin{array}{l}\text { I believe the government/ state financial } \\
\text { institutions help to set up infrastructure that } \\
\text { has a positive role in promoting P2P } \\
\text { lending applications. }\end{array}$ \\
\hline \multirow{3}{*}{$\begin{array}{l}\text { Attitude } \\
\text { Towards Using } \\
\text { Technology }\end{array}$} & ATT1 & $\begin{array}{l}\text { I believe using P2P lending is an interesting } \\
\text { idea. }\end{array}$ \\
\hline & ATT2 & I believe using P2P lending is a good idea. \\
\hline & ATT3 & $\begin{array}{l}\text { I am interested in using P2P lending } \\
\text { services. }\end{array}$ \\
\hline $\begin{array}{l}\text { Intention to } \\
\text { Use }\end{array}$ & INT1 & $\begin{array}{l}\text { If I had to choose to make a loan, I would } \\
\text { choose P2P lending services. }\end{array}$ \\
\hline
\end{tabular}

\begin{tabular}{|l|l|l|}
\hline Variable & Code & \multicolumn{1}{c|}{ Indicator } \\
\hline \multirow{2}{*}{} & INT2 & $\begin{array}{l}\text { I intend to use P2P lending services in the } \\
\text { future. }\end{array}$ \\
\cline { 2 - 3 } & INT3 & $\begin{array}{l}\text { I will often use P2P lending services in the } \\
\text { future. }\end{array}$ \\
\cline { 2 - 3 } INT4 & $\begin{array}{l}\text { I would recommend using P2P lending } \\
\text { services. }\end{array}$ \\
\hline
\end{tabular}

\section{REFERENCES}

1. Abadi, T. (2019). Pengaduan Konsumen dan Kinerja $O J K$. Accessed on 3 April 2020, from http://ylki.or.id/2020/01/pengaduan-konsumen-dan-kine rja-ojk/

2. Adi. (2019). Gabungan OJK dan Polri di Satgas Waspada Investasi Komitmen Menindak Investasi dan Fintech Ilegal. Accessed on 5 April 2020, from https://pasardana.id/news/2019/8/2/gabungan-ojk-dan-p olri-di-satgas-waspada-investasi-komitmen-menindak-in vestasi-dan-fintech-ilegal/ https://doi.org/10.1007/s12525-012-0106-2

3. Alt, R., \& Puschmann, T. (2012). The Rise of Customer-Oriented Banking - Electronic Markets are Paving the Way for Change in the Financial Industry. Electronic Markets, 22(4), 203-215.

4. Amin, M. K., Azhar, A., Amin, A., \& Akter, A. (2015). Applying the Technology Acceptance Model in Examining Bangladeshi Consumers' Behavioral Intention to Use Mobile Wallet: PLS-SEM Approach. In the 2015 18th International Conference on Computer and Information Technology (ICCIT), 93-98.

5. Arif, I., Afshan, S., \& Sharif, A. (2016). Resistance to Mobile Banking Adoption in a Developing Country: Evidence from Modified TAM Model. Journal of Finance \& Economic Research, 1(1), 24-41.

6. Arsanti, T.A., \& Yuliasari, E. (2018). Personal Factors as Predictors of Intention to Use IT. Jurnal Manajemen dan Kewirausahaan, 20(2), 129-136. https://doi.org/10.9744/jmk.20.2.129-136

7. Asosiasi Penyelenggara Jasa Internet Indonesia. (2019). Laporan Survey Penetrasi dan Profil Perilaku Pengguna Internet Indonesia 2018 (Ver.: S 20190518). Accessed on 25 July 2019 from https://apjii.or.id/survei

8. Bartels, J., \& Reinders, M.J. (2011). Consumer Innovativeness and its Correlates: A Propositional Inventory for Future Research. Journal of Business Research, 64(6), 601-609.

9. Beckner, K. (2018). Managing Millennial Workers: A Multigenerational Approach. Emerging Writers, 1(12). https://doi.org/10.32832/moneter.v7i1.2515

10. Bimo, W.A., \& Tiyansyah, A. (2019). Peran Otoritas Jasa Keuangan dalam Mengawasi Pinjaman Berbasis Teknologi Informasi (Fintech Lending). Moneter: Jurnal Keuangan dan Perbankan, April 2019 7(1), 26-33.

11. Bultum, A.G. (2014). Factors Affecting the Adoption of an Electronic Banking System in the Ethiopian Banking Industry. Journal of Management Information System 
Nancy Adistyasari et al., International Journal of Advanced Trends in Computer Science and Engineering, 9(2), March - April 2020, 2010 - 2020

and E-commerce, 1(1).

12. Chandra, S., Srivastava, S., \& Theng, Y. (2010). Evaluating the Role of Trust in the Consumer Adoption of Mobile Payment Systems: An Empirical Analysis. Communications of the Association for Information Systems, 27(1), 561-588.

13. Chang, Y., Wong, S. F., Lee, H., \& Jeong, S. P. (2016). What Motivates Chinese Consumers to Adopt Fintech Services: A Regulatory Focus Theory. Proceedings of the International Conference on Electronic Commerce: E-Commerce in Smart Connected World. https://doi.org/10.1145/2971603.2971643

14. Chatterjee, D., \& Bolar, K. (2018). Determinants of Mobile Wallet Intentions to Use: The Mental Cost Perspective. International Journal of Human-Computer Interaction, 1-11.

15. Chauhan, M., \& Shingari, I. (2017). Future of e-Wallets: A Perspective from Undergraduates. International Journals of Advanced Research in Computer Science and Software Engineering, 7(8), 146-150.

16. Chong, A.Y.L., Ooi, K.B., Lin, B., \& Tan, B.I. (2010). Online Banking Adoption: An Empirical Analysis. International Journal of Bank Marketing, 28, 267-287. https://doi.org/10.1108/02652321011054963

17. Chuang, L. M., Liu, C. C., \& Kao, H. K. (2016). The Adoption of Fintech Service: TAM Perspective. International Journal of Management and Administrative Sciences, 3(7), 1-15.

18. DailySocial. (2018). Fintech Report 2018. Accessed on 20 February 2020, from https://dailysocial.id/ report/post/fintech-report-2018

19. DailySocial. (2019). Moving towards a New Era in Indonesia's Financial Industry - Fintech Report 2019. Accessed on 20 February 2020, from https://dailysocial.id/report/post/fintech-report-2019

20. Davis, F. D. (1986). A Technology Acceptance Model for Empirically Testing New End-User Information Systems: Theory and Results. Massachusetts, United States: Sloan School of Management, Massachusetts Institute of Technology.

21. Davis, F. D. (1989). Perceived Usefulness, Perceived Ease of Use, and User Acceptance of Information Technology. MIS Quarterly, 13(3), 319-340.

22. Davis, K., Maddock, R., \& Foo, M. (2017). Catching Up with Indonesia's Fintech Industry. Law Financial Markets Review, 11(1), 33-40. https://doi.org/10.1080/17521440.2017.1336398.

23. Dewi, I.G.A.A.P. (2018). Intensi Masyarakat Berinvestasi pada Peer-to-Peer Lending: Analisis Theory of Planned Behavior. Jurnal Ilmiah Akuntansi \& Bisnis, 3(2), 118-132.

24. Dorfleitner, G., Honruf, G., Schmitt, M., \& Martina, W. (2017). FinTech in Germany. Switzerland: Springer. https://doi.org/10.1007/978-3-319-54666-7

25. Fishben, M., \& Ajzen, I. (1975). Belief, Attitude, Intention, and Behavior: An Introduction to Theory and Research. Reading, Mass; Don Mills, Ontario:
Addison-Wesley Pub.Co.

26. Gai, K., Qiu, M., \& Sun, X. (2018). A Survey on FinTech. Journal of Network and Computer Applications, 103(February), 262-273.

27. Gupta, A., \& Arora, N. (2017). Consumer Adoption of M-Banking: A Behavioral Reasoning Theory Perspective. International Journal of Bank Marketing, 35, 733-747.

28. Haidari, M., \& Tileng, K. (2018). Analisa Faktor-Faktor Berpengaruh pada Penggunaan Go-Pay. JUISI, 4(1). $10-15$.

29. Hair, J.F., Anderson, R.E., Tatham, R.L., \& Black, W.C. (1998). Multivariate Data Analysis. New Jersey: Prentice Hall.

30. Hair, J.F., Ringle, C.M., \& Sarstedt, M. (2011). PLS-SEM: Indeed a Silver Bullet. The Journal of Marketing Theory and Practice, 19(2), 139-151. https://doi.org/10.2753/MTP1069-6679190202

31. Hanafizadeh, P., Behboudi, M., \& Koshksaray, A. (2014). Mobile-Banking Adoption by Iranian Bank Clients. Telematics and Informatics, 31, 62-78.

32. Hidayanto, A.N., Hidayat, L.S., Sandhyaduta, P.I., \& Handayani, I.P.W. (2015). Examining the Relationship of Payment System Characteristics and Behavioural Intention in E-Payment Adoption: A Case of Indonesia International. Journal Business Information Systems, 19(1), 58-86.

33. Hsu, C.L., Wang, C.F., \& Lin, J.C.C. (2011). Investigating Customer Adoption Behaviours in Mobile Financial Services. International Journal of Mobile Communications, 9, 477-494. https://doi.org/10.1504/IJMC.2011.042455

34. Hsu, C.L. \& Lin, J.C.C. (2016). Effect of Perceived Value and Social Influences on Mobile App Stickness and In-App Purchase Intention. Technological Forecasting and Social Change, 108, 42-53.

35. Hu, Z., Ding, S., Li, S., Chen, L., \& Yang, S. (2019). Adoption Intention of Fintech Services for Bank Users: An Empirical Examination with an Extended Technology Acceptance Model. Symmetry, 11, 340.

36. Hussein A.S. (2015). Penelitian Bisnis dan Manajemen Menggunakan Partial Least Squares (PLS) dengan SmartPLS 3.0. Universitas Brawijaya.

37. Indrawati, \& Putri, D.A. (2018). Analyzing Factors Influencing Continuance Intention of E-Payment Adoption Using Modified UTAUT 2 Model. 2018 6th International Conference on Information and Communication Technology (ICoICT), 167-173. https://doi.org/10.1109/ICoICT.2018.8528748

38. Isnaini, M. (2017). Gerakan Kerelawanan Generasi Milenial: Kasus pada Pemilihan Kepala Daerah (Pilkada) Jakarta 2017 dalam Perspektif Komunikasi Politik. Kolas Komunikasi di Indonesia.

39. Jiwasiddi, A., Adhikara, C.T., Adam, M., \& Triana, I. (2019). Attitude toward Using Fintech among Millennials. Workshop on Multimedia Education, Learning, Assessment and Its Implementation in Game 
Nancy Adistyasari et al., International Journal of Advanced Trends in Computer Science and Engineering, 9(2), March - April 2020, 2010 - 2020

and Gamification in Conjunction with COMDEV 2018, Medan Indonesia, 26th January 2019.

40. Kapoor, C., \& Solomon, N. (2011). Understanding and Managing Generational Differences in the Workplace. Worldwide Hospitality and Tourism Theme, 3, 308-318.

41. Kholis. (2018). Perbankan dalam Era Baru Digital. Economicus, 9(1). 80-88. https://doi.org/10.1108/17554211111162435

42. Khudoyberdiyev, D. (2019). The Factors Serving to Form Personal Consumptive Conduct. International Scientific Journal Theoretical \& Applied Science, 72(4), 489-492. https://doi.org/10.15863/TAS.2019.04.72.62

43. Kim, C., Mirusmonov, M., \& Lee, I. (2010). An Empirical Examination of Factors Influencing the Intention to Use Mobile Payment. Computers in Human Behavior, 26, 310-322.

44. Kiwanuka, A. (2015). Acceptance Process: The Missing Link between UTAUT and Diffusion of Innovation Theory. American Journal of Information Systems, 3(2), 40-44.

45. Kumar, A., \& Mukharjee. (2014). Shop while You Talk: Determinants of Purchase Intentions through a Mobile Device. International Journal of Mobile Marketing, 8(1), 23-37.

46. KPMG Sidartha Advisory. (2018). The Fintech Edge, First Edition: Peer-to-Peer Lending. Accessed on 16 November 2019, from https://home.kpmg/id/en/home/insights/2018/11/id-the-fi ntech-edge-p2p-lending.html

47. Lee, S. (2016). User Behavior of Mobile Enterprise Application. KSII Transaction on Internet and Information Systems, 10(8), 3972-3985.

48. Lee, S. (2017). Evaluation of Mobile Application in User's Perspective: Case of P2P Lending Apps in FinTech Industry. KSII Transactions on Internet and Information Systems, 11(2), 1105-1117.

49. Manurung, R., \& Rahardjo, A. (2019). Faktor Pendukung Keputusan UMKM dalam Mengambil Modal Usaha dengan Model Peer-to-Peer (P2P) Lending. Seminar Nasional Edusainstek, FMIPA UNIMUS 2019, 438-445.

50. Marakarkandy, B., Yajnik, N., \& Dasgupta, C. (2017). Enabling Internet Banking Adoption: An Empirical Examination with an Augmented Technology Acceptance Model (TAM). Journal of Enterprise Information Management, 30(2), 263-294.

51. Mardiana, S., Tjakraatmadja, J.H., \& Aprianingsih, A. (2015). DeLone-McLean Information System Success Model Revisited: The Separation of Intention to Use and the Integration of the Technology Acceptance Model. International Journal of Economics and Financial Issues, 15(1S), 172-182.

52. McAuley, D. (2014). What is FinTech? Accessed on 1 October 2019, from https://medium.com/ wharton-fintech/what-is-fintech-77d3d5a3e677

53. Meyliana, Fernando, E., \& Surjandy. (2019). The Influence of Perceived Risk and Trust in the Adoption of FinTech Services in Indonesia. CommIT
(Communication \& Information Technology) Journal, 13(1), 31-37.

54. Mun, Y.P., Khalid, H., \& Nadarajah, D. (2017). Millennials' Perception on Mobile Payment Services in Malaysia. Procedia Computer Science, 124, 397-404.

55. Nasri, W., \& Charfeddine, L. (2012). An Exploration of Facebook.com Adoption in Tunisia Using the Technology Acceptance Model (TAM) and Theory of Reasoned Action. Interdisciplinary Journal of Contemporary Research in Business, 4(5), 948-968.

56. Nugroho, M.A. (2015). Impact of Government Support and Competitor Pressure on the Readiness of SMEs in Indonesia in Adopting the Information Technology. Proceedia Computer Science, 75, 102-111.

57. Otoritas Jasa Keuangan. (2019). Data Statistik OJK Fintech Lending 2019. Accessed on 6 November 2019, from https://www.ojk.go.id/id/kanal/iknb/data-dan-statistik/fi ntech/Pages/Statistik-Fintech-Lending-Periode-Juli-201 9.aspx

58. Perkins, E.D., \& Annan, J. (2013). Factors Affecting the Adoption of Online Banking in Ghana: Implications for Bank Managers. International Journal of Business and Social Research, 3(6).

59. Punwatkar, S., \& Verghese, M. (2018). Adaptation of e-Wallet Payment: An Empirical Study on Consumers' Adoption Behavior in Central India. International Journal of Advancements in Management, Technology, and Engineering Sciences, 8(3), 1147-1156.

60. PwC Financial Services Institute. (2016). Q\&A: What is Fintech? Accessed on 6 November 2019, from https://www.pwc.com/us/en/industries/financial-services /library/qa-what-is-fintech.html

61. PwC. (2019). Indonesia's Fintech Lending: Driving Economic Growth through Financial Inclusion. Accessed on 28 September 2019, from https://www.pwc.com/id/en/fintech/PwC_FintechLendin gThoughtLeadership_ExecutiveSummary.pdf

62. Rahayu, R., \& Day, J. (2015). Determinant Factors of E-commerce Adoption by SMEs in Developing Country: Evidence from Indonesia. Procedia Social and Behavioral Sciences, 195, 142.150.

https://doi.org/10.1016/j.sbspro.2015.06.423

63. Respati, A. (2019). Per Juni 2019, Ada 4.500 Aduan Pinjaman Fintech yang Masuk ke LBH Jakarta. Accessed on 5 April 2020, from

https://keuangan.kontan.co.id/news/per-juni-2019-ada-4 500-aduan-pinjaman-fintech-yang-masuk-ke-lbh-jakarta

64. Riyanto, A., Primiana, I., Yunizar, \& Azis, Y. (2018). Disruptive Technology: The Phenomenon of FinTech towards Conventional Banking in Indonesia, IOP Conf. Series: Materials Science and Engineering, 407 (2018) 012104 doi:10.1088/1757-899X/407/1/012104.

65. Rizal, M., Maulina, E., \& Kostini, N. (2018). Fintech as One of the Financing Solutions for SMEs. AdBispreneur: Jurnal Pemikiran dan Penelitian Administrasi Bisnis dan Kewirausahaan, 3(2), 89-100. 
Nancy Adistyasari et al., International Journal of Advanced Trends in Computer Science and Engineering, 9(2), March - April 2020, 2010 - 2020

66. Rogers, E.M. (1995). Diffusions of Innovations. New York, NY: The Free Press.

67. Rosavina, M., \& Rahadi, R. (2018). Peer-to-Peer (P2P) Lending Platform Adoption for Small Medium Enterprises (SMEs): A Preliminary Study. International Journal of Accounting, Finance, and Business, 3(10), $1-14$.

68. Ryu, H. (2018). What Makes Users Willing or Hesitant to Use Fintech?: The Moderating Effect of User Type. Industrial Management \& Data System, 118, 541-569.

69. Schierz, P.G., Schilke, O., \& Wirtz, B.W. (2010). Understanding Consumer Acceptance of Mobile Payment Services: An Empirical Analysis. Electronic Commerce Research and Applications, 9(3), 209-216.

70. Seetharaman, A., Kumar, K.N., Palaniappan, S., \& Weber, G. (2017). Factors Influencing Behavioral Intention to Use the Mobile Wallet in Singapore. Journal of Applied Economics and Business Research, 7(2), 116-136.

71. Setiobudi, A., \& Trianggoro, W. (2018). Intensi UKM dalam Adopsi Financial Technology di Jawa Timur. National Conference of Creative Industry: Sustainable Tourism Industry for Economic Development. Universitas Bunda Mulia, Jakarta, 5-6 September 2018, 476-490.

72. Septiari, E.D., \& Kusuma, G.H. (2016). Understanding the Perception of the Millenial Generation towards the Traditional Market (A Study in Yogyakarta). Review of Integrative Business and Economics Research, 5(1), 30-43.

73. Sevim, N., \& Hall, E.R. (2014). Consumer Trust Impact on Online Shopping Intent. Journal of Uygulamari ve Yonetimi Applications and Management, 5(2), 20-28.

74. Shaikh, A.A. \& Karjaluoto, H. (2015). Mobile Banking Adoption: A Literature Review. Telematics and Informatics, 32, 129-142.

75. Sharma, S.K., Mangla, S.K., Luthra, S., \& Al-Salti, Z. (2018). Mobile Wallet Inhibitors: Developing a Comprehensive Theory Using an Integrated Model. Journal of Retailing and Consumer Services, 45, 52-63.

76. Shin, D.H. (2013). User Experience in Social Commerce: In Friends, We Trust. Behaviour \& Information Technology, 32(1), 52-67.

https://doi.org/10.1080/0144929X.2012.692167

77. Sundjaja, A.M., \& Tina, A. (2019). The Factors of the Intention to Use P2P Lending Financial Technology (Fintech) Website at Jadetabek Intervening by Perceived Value. International Journal of Recent Technology and Engineering, 8(3), 3102-3107.

78. Suyanto, \& Kurniawan, T.A. (2019). Faktor yang Mempengaruhi Tingkat Kepercayaan Penggunaan FinTech pada UMKM dengan Menggunakan Technology Acceptance Model (TAM). Jurnal Akuntansi \& Manajemen Akmenika, 16(1), 175-186.

79. Tandiono, J., Djojo, B.W., Candra, S., \& Heriyati, P. (2020). Finding the Customer Perception of Peer-to-Peer (P2P) Lending Financial Technology in Pohon Dana.
Binus Business Review, 11(1), 51-58.

80. Taylor, S., \& Todd, P.A. (1995). Understanding Information Technology Usage: A Test of Competing Models. Information Systems Research, 6, 144-176.

81. Thaker, M. A. B. M. T., Thaker, H. B. M. T., Rahman, M.P.B., Amin, M.F.B., Pitchay, A.B.A., \& Olaniyi, N.O. (2019). Factors Affecting Investors' Intention to Invest in a Peer-to-Peer Lending Platform in Malaysia: An Extended Technology Acceptance Model. ADBI Working Paper 998. Tokyo: Asian Development Bank Institute.

82. Tunay, N., Yüksel, S., \& Tunay, K.B. (2019). The Effects of Technology on Bank Performance in Advanced and Emerging Economies: An Empirical Analysis. DOI:10.4018/978-1-5225-7180-3.ch015

83. Venkatesh, V., \& Davis, F.D. (1996). A Model of the Antecedents of Perceived Ease of Use: Development and Test. Decision Sciences, 27(3), 451-481.

84. Venkatesh, V., \& Davis, F.D. (2000). A Theoretical Extension of the Technology Acceptance Model: Four Longitudinal Field Studies. Management Science, 46 (2), 186-204.

85. Yuniarti, V. (2019). Faktor-faktor yang Mempengaruhi Minat Penggunaan Financial Technology Peer-to-Peer Lending. Jurnal Ilmiah Mahasiswa FEB, 8(1).

86. Zarmpou, T., Saprikis, V., \& Vlachopoulou, M. (2012). Modelling Users' Acceptance of Mobile Service. Springer Science Business and Media, 10(12), 225-248.

87. Zhao, A.L., Koenig-Lewis, N., Hammer-Lloyd, S., \& Ward, P. (2010). Adoption of Internet Banking Services in China: Is It All about Trust? International Journal of Bank Marketing, 28, 26.

88. Ng, A.W. \& Kwok, B.K.B. (2017). Emergence of Fintech and Cybersecurity in a Global Financial Centre: Strategic Approach by a Regulator. Journal of Finance Regulation and Compliance, 25, 422-434.

89. Lu, J. (2014). Are Personal Innovativeness and Social Influence Critical to Continue with Mobile Commerce? Internet Research, 24(2), 134-159.

90. Zhang, L. \& Cao, S. Y. (2017). Research on the Factors Affecting the Borrowing Efficiency of P2P Online Lending. In 2017 3rd Interntional Conference on Social, Education and Management Engineering, 119-125.

91. Panggati, I.E., Wandoko, W., Sasmoko., Simatupang, B., Abdinagoro, S.B. (2019). Factors Affecting Consumers Attitudes towards a brand that uses Digital Advertising. International Journal of Advanced Trends in Computer Science and Engineering, 8(5), 1869-1875. https://doi.org/10.30534/ijatcse/2019/09852019

92. Wang, G., Jonathan, Gunawan, V.A. (2019). Success Factors Influencing Consumers' Willingness to Purchase Brand Advertised Through Mobile Phone in Indonesia. International Journal of Advanced Trends in Computer Science and Engineering, 8(5), 2581-2585. https://doi.org/10.30534/ijatcse/2019/108852019 